\title{
Industrial Nationalism versus European Partnerships: An Analysis of State-led Franco-German Inter-firm Linkages
}

\begin{abstract}
:
This paper examines the impact of state intervention in French-German inter-firm linkages and discusses the implications of conflicting national interests for the furthering of single market integration. It demonstrates that despite initial success in launching large-scale cross-border alliances in strategic sectors, France and Germany have remained divided by their own industrial nationalism. It argues that their respective attitudes towards industrial policy are less contradictory than would appear at first sight, but that transcending industrial nationalism by Europeanising the notion of economic patriotism would be an essential pre-condition for a more efficient EU-wide industrial policy within a better integrated internal market.
\end{abstract}

Key words: Co-operative alliances, Government-industry relations, Industrial nationalism, Industrial policy, Inter-firm linkages, State intervention.

\section{Introduction}

Industrial cooperation between France and Germany has frequently drawn media attention, sometimes claiming ambitious achievements, sometimes highlighting shortcomings or hidden inter-state rivalries. Numerous inter-firm linkages have been established across the Rhine, particularly in the past two decades, some of which were politically enforced. State-led industrial co-operation between the two countries has led to corporate successes, most of whom have been eroded by industrial nationalism, often leading to striking failures. This empirical study examines Franco-German cross-border linkages, and focuses on cases where state interference has been instrumental in implementing these linkages.

Several reasons justify the need to explore state-led inter-firm linkages in the specific context of Franco-German industrial co-operation. First, the French and the German economies correspond to two varieties of capitalism ( $\mathrm{VoC})$ sharing important features, but distinct in 
terms of the role that the state plays, or attempts to play, in the economy. French industry tends to be state-directed, whereas industrial developments in Germany tend to be stateenabled (Schmidt 2002). This raises crucial questions as to how the two sides' diverging interpretations of what industrial policy entails, and how their respective institutional structures and modes of government-industry relations impact upon the principle of grouping together firms and sectors from the two countries. Second, France and Germany, who both pledge to have established a unique relationship at the forefront of European construction, have reached a high level of economic and political interdependence which, at first glance, appears to make them well suited for facilitating or implementing cross-border linkages between their home firms. They are indeed bound together by a tightly woven web of trade and investment relations which increases macroeconomic interdependence (despite lack of fiscal and macro-economic convergence) between their national economies. Moreover, they have been each other's main supplier and purchaser of goods and services year after year (despite persistent imbalance in their inter-trade relationships) as well as one of the other's main investors, reflecting a high level of industrial intertwinement ${ }^{1}$. Third, the fact that these two countries are the biggest Eurozone economies, which have kept the largest manufacturing base in Europe, adds to this study's relevance.

Industrial relations between France and Germany are indeed a relevant aspect of European economic integration (Artus 2009). The declared aim of these relations has been to promote European champions in areas where comparative advantages could benefit from being combined with critical mass. However, this research highlights the discrepancy between declared aims and real outcomes, rhetoric and reality. Frequently hampered by inter-state rivalries, bilateral industrial co-operation has proved to be the most difficult field of

\footnotetext{
${ }^{1}$ However, since 2011 the Netherlands and China have been exporting more to Germany than France.
} 
intergovernmental co-operation (Cromme 2005, Uterwedde 2009). This ambivalence between co-operation and rivalry raises important issues, both in terms of furthering European integration and from a business perspective, with respect to state interference in crossnational inter-firm linkages, the desirability of enforcing these linkages by means of political intervention, and more generally the role of the state in promoting, or preventing, steps towards Europeanising national industries. Assessing the efficiency of French-German cooperation in this area provides useful indications about limitations to potential systemic convergence, for instance when it comes to merging technologies, harmonising production processes, combining talents, sharing ownership or agreeing on new managerial structures in an equitable way. Hence, Franco-German industrial conflicts emphasize the discrepancy between declared partnership and underlying rivalry as well as national obstacles to European integration. The quality of bilateral industrial co-operation, and more generally the way that states interact with each other and with business to create different forms of economic cooperation, can serve as a test bench with regard to furthering industrial integration within the Single Market.

Since the Single Market was launched, numerous attempts have been made by EU memberstates to prevent, on nationality grounds, companies from other parts of Europe from taking over their industrial flagships. Restrictive national measures to limit ownership transfer through cross-border corporate mergers and acquisitions (M\&A) raise legal issues since they contravene fundamental internal market principles on free capital movement and the right of establishment. They also raise crucial economic issues since the European economy can only prosper by removing barriers within an open competitive Single Market rather than erecting new obstacles between member states. What are the implications of conflicting national interests for the EU's efforts to consolidate the Single Market and generate a 'corporate 
Europe'? At a time when re-launching the Single Market is on the EU's agenda (Monti 2010; COM 2010), and in a backdrop of rising economic nationalism, there is a need to re-appraise the impact of political activism in attempting to build or consolidate industrial champions in Europe. Issues such as 'champion-building' (Hayward 1995, Seabright 2005, Mosconi 2006), economic patriotism (Landier and Thesmar 2005, Wruuck 2006) or the nationality of companies (Levet 2000, Véron 2006) are frequently at the heart of academic and policy debates on internal market integration and the future of European industry. Divergences about what industrial policy should entail is a recurrent source of conflicts between Brussels and member-states as well as between Berlin and Paris (Trouille 2007). The present paper proposes the following roadmap. First, it highlights the role of state intervention as a distinctive feature that differentiates the French from the German VoC, stresses its importance in cross-border linkages regarded as 'strategic', and investigates modes of state involvement corresponding to different French and German conceptions of industrial policy. There is indeed a fundamental difference in the way that government-industry relations are organised in France and in Germany. This difference, which is at the source of conflicts in intergovernmental cooperation, concerns the respective influence of the state in the French and the German institutional structures and corporate cultures. The VoC perspective (Hall and Soskice 2001, Hancké et al. 2007) provides a useful theoretical framework to assess the role played by the state in distinct national patterns of market co-ordination and to explain the variance between French and German state intervention and industrial policies. Second, this paper empirically analyses emblematic cases of state-induced Franco-German corporate alliances. For this purpose, extensive data was collected about all state-influenced groupings of French and German firms in order to examine whether failed or aborted state-led linkages are business-inherent, or whether failures may have been caused by unco-operative or obstructive state interference. Finally the paper draws conclusions on the conditions that 
these two distinct approaches of industrial policy would need to fulfil for successfully promoting cross-national inter-firm linkages in Europe.

\section{Co-ordination or Intervention: Industrial Policy, the State and the VoC Perspective}

Issues of public intervention and interventionist policy-making have been widely covered by Environment and Planning C (Atherton 2006, Bennett 2008), sometimes with a focus on France or Germany (Sternberg et al 2010, Menu 2012). Existing literature on various modes of market entry focusing on French and German firms tends to concentrate on comparing their expansion strategies. This literature provides primarily comparative analysis of their respective domestic and cross-border (European and transatlantic) operations or looks into the influence of these companies' national origins on their alliance strategies (Urban et al. 2000, Mayrhofer 2001, 2004), but does not specifically address state interference in interfirm linkages. This analysis of state-led Franco-German inter-firm linkages aims to demonstrate on the basis of empirical evidence the systematic impact of diverging conceptions of the role of the state within the institutional organisations of national economies on inter-state industrial co-operation. The $\mathrm{VoC}$ school of analysis provides a pertinent framework to sustain this theoretical claim and explain the variance between French and German state intervention and industrial policies. Distinct patterns of state co-ordination or intervention resulting from these diverging conceptions correspond, indeed, to different varieties of capitalism, and these differences are replicated in different understandings and national industrial policy practices.

The VoC literature identifies various forms of economies, ranging from two 'ideal-type' models of capitalism, referred to as 'liberal' and 'co-ordinated' market economies (LMEs and 
CMEs), to 'mixed-market' and 'emerging market' economies (MMEs and EMEs). Based on this typology, Hancké et al. (2007) make up for the relative absence of the role of the state in Hall and Soskice's initial iteration of VoC theory formulation (2001) and explore several dimensions of the role played by the state in shaping and co-ordinating various types of contemporary capitalism. Whilst the role played by the state in an economy is only one parameter amongst others in order to identify and contrast VoCs, we believe that it is an important one. In every modern economy, relations between the state and the supply-side of the economy are indeed a relevant determining variable, but these relations take different forms according to the type of capitalism concerned. Different degrees of state involvement can be observed, and still persist today, in various modern economies. In some 'stateinfluenced' market economies (SMEs) like China, Russia and pre-1990 France, an activist state owns large sectors, controls industrial credit and maintains close direct influence over the economy, as a central actor in economic and industrial policy-making, providing both a framework for business activities and a means of pursuing them. In other economies (Germany, the Netherlands, Scandinavian countries), the state is one element of co-ordination among others which acts primarily as a regulator operating at arm's length. Rather than being a direct promoter of economic activity, it acts as a compensator in co-ordinating deficits and structural change and as a provider of economic consensus. In still other economies corresponding to the liberal Anglo-Saxon model, the state has traditionally allowed markets to operate within a broad set of regulatory frameworks, refraining from direct interference.

However, such differences are not always as clear-cut as they used to be. Traditional capitalist models in Europe have undergone deep transformations through a combination of economic pressures resulting from globalisation and pressures for policy convergence emanating from Europe (Callaghan 2008). This certainly applies to France and Germany. 
Whilst the German model is widely regarded among scholars as a CME, some also classify France as a CME, others as an MME, or as an SME. Schmidt (2002) argues that nationally based varieties continue to predominate and develops her own typology of capitalist models in Europe, separating 'state capitalism' (French statism) from 'managed capitalism' (German corporatism) and 'market capitalism' (British liberalism). Schmidt (2003, 2008, 2009) insists that despite having evolved in a market-oriented direction, transformed French capitalism still constitutes a specific variety where an 'interventionist' state organises inter-firm collaboration and imposes management-labour co-operation. Uterwedde (2009) acknowledges these fundamental differences between the French and German models, one characterised by a dirigist state leading post-war modernisation, the other by ordoliberalism and the social component of its market economy, but also highlights similarities and elements of convergence between two continental European models distinct from the Anglo-Saxon LME type. Monti (2010), in his recent reflexion on re-vitalising the Single Market by proposing a suitable compromise between concerns of Anglo-Saxon free market economies and of continental social market economies, ranks both the French and German VoCs in the second category.

In this paradigm, it is necessary to understand the changing role of the state from pre- to post1990 France. During the Trente glorieuses ${ }^{2}$, the state played a paramount role in defining, supporting and organising the post-war growth model. Economic modernisation was a topdown process orchestrated through active state intervention. Modernisation strategies relied upon major industrial projects ${ }^{3}$ initiated by the state in the framework of a large public sector encompassing banking and finance, and aimed at shaping 'national champions' with stateinfluenced mergers (Cohen 1992, Maclean 2002, Gaudard 2005). But the 1970s' economic

\footnotetext{
2 The ' 30 glorious years' of uninterrupted post-war economic expansion.

${ }^{3}$ Nuclear energy, transport infrastructures, aeronautics, defence and space technologies, high-speed trains, information and communication technologies.
} 
crises marked a retreat from state intervention throughout Europe. From the mid-1980s, with economic liberalisation and the run-up towards the Single Market, the state exerted pressure from below, subjecting firms to increasing market competition (Hancké et al. 2007:55). Significant pillars of dirigisme were dismantled by successive governments, 'albeit without forsaking all of its rhetoric', as Hall (Hancké et al. 2007:63) notes. A rapid transformation of French capitalism took place, which was described as 'a revolution (...) changing the whole economic and social framework of the country, the way of working as much as the conditions of redistribution or the social dialogue' (Izraelevicz 1999:279). Today's French economy has a high degree of openness in trade, foreign investment, and in the capital structure of its large firms: the share of foreign investors in the capital of French firms has become one of the highest in modern economies ${ }^{4}$. Dirigisme gradually gave way to a reduced state, more openness, a wider acceptance of privatisations and less hostility towards market deregulation. Policy-makers endeavoured to adjust to this new context, without upsetting an electorate expecting the state to act as a bulwark against negative social consequences of economic globalisation. This led to a pragmatic combination between traditionalism and modernism, a shift from Keynesianism to more 'horizontal' supply-side policies aiming to shape a business-friendly environment, and less direct intervention (Trouille and Uterwedde 2008; 2013). The compétitivité globale ${ }^{5}$ approach (Colletis et al. 2001) reshaped public interventionism, with the state becoming gradually a partner in a system of multiple private and public actors, in which 'soft' competitiveness factors such as innovation, knowledge, and co-operation became more prominent in public policies (Colletis and Levet 1997). This policy adjustment to enable the French economy to keep up with international competition was nonetheless coupled with efforts to retain a sizeable public steering capacity as a compromise between passive adaptation and illusory national resistance to globalisation.

\footnotetext{
${ }^{4}$ With the exception of Central and Eastern European economies.

${ }^{5}$ Global competitiveness.
} 
Later, the Sarkozy era marked an apparent return to more interventionist supply-side policies as a means of asserting France's position as a strong industrial nation on the world stage, in particular through pro-active strategies to promote national champions. Priority given to national considerations intensified to become a leitmotiv of Sarkozy's ethnocentric attitude towards industrial policy, generating serious conflicts (takeover, endorsed by the French political establishment, of Franco-German pharmaceutical group Aventis by a smaller French company (see Appendix table T1-case A11); re-capitalisation of engineering group Alstom to prevent Siemens from stepping in (T3-C7); national rivalries within EADS $^{6}$ (T1-A1)) and paving the way towards French state-controlled 'world champions' brandishing the national flagship in the energy $\left(\mathrm{GDF}^{7}-\mathrm{Suez}\right)$ and nuclear sectors (Areva: T3-C2) to the detriment of German competitors (Eon) and partners (Siemens) alike. However, today's economic impact of the French state no longer compares with its omnipotence in post-war times. Complying with EU regulations adds constraints which contain temptations to revert to old-type sectoral industrial policies. This ambivalent stance between traditional and pragmatic attitudes explains scholars' dilemma when attempting to classify the French VoC as an MME, a CME or as separate SME entity.

Unlike the dirigist model of pre-1990 France, the managed, co-ordinated German capitalism unequivocally referred as early as 1948 to liberal economic values and market openness. Economic liberalism, initially epitomised by Erhard's concept of soziale Marktwirtschaft ${ }^{8}$, has been dominant throughout the post-war period. But in practice it combined its liberal framework with a dense network of corporatist regulations worked out by labour and industrial organisations, and active local and regional forms of public intervention. Despite a high degree of openness in trade and investment, Rhineland capitalism has been characterised

\footnotetext{
${ }^{6}$ European Aeronautics, Defence and Space Company.

${ }^{7}$ Gaz de France.

${ }^{8}$ Social Market Economy.
} 
by a national capital structure and collective attitudes making friendly or unfriendly takeovers of German firms by foreign groups more difficult (Streeck 1996). Under the combined effect of German unification and European integration, the German political economy has also had to respond to considerable adaptational pressures (Dyson and Goetz 2003). Characterised by its consensus-oriented mechanisms of industrial and social relations facilitated by an 'enabling' state, the German CME was able to rely on the co-operative management of economic change and domestic policy adaptation. It addressed pressures for change by reconfiguring its institutional arrangements to introduce more flexibility into its model whilst trying not to alter its main characteristics.

Pressures for change have therefore not fundamentally altered a German approach to industrial policy which has, traditionally, been implicit and less noticeable than in France (Uterwedde 2009). Whereas state intervention in French industry is perceived as natural and legitimate, its scope is much more limited in Germany, where the state has neither the same legitimacy nor similar policy instruments at its disposal. Until the early 2000s, for reasons inherent to post-war economic, political and social culture, the concept of industrial policy was virtually absent from official discourse. Painful recollections of the centralised war economy, coupled with a rejection of the former East-German command economy model, shaped its 'horizontal' dimension within the framework of the social market economy (Levet 2005), in which the state's role consists primarily of developing a regulatory framework (Ordnungspolitik) to ensure equilibrium between market and social justice. This implies that public action remains by nature decentralised in a context where the state is only one partner out of a wide range of actors, in particular the 16 region-states (Länder), the local councils (Stadtwerke), which contribute actively to implementing regional strategies of economic and 
industrial development, and professional organisations (Verbände), which frequently act as intermediaries of public regulation across various sectors.

However, German attitudes towards industrial policy have arguably been more ambiguous than French ones. Germany has frequently resorted to measures resembling French public interventions to avoid losing national control of home companies. In the old-type Deutschland $A G^{9}$, collective attitudes and cross-ownerships between banks, insurance groups and industry have traditionally sheltered domestic firms from foreign takeovers (Streek 1996). Endeavours to preserve Lower Saxony's role as a major shareholder of the Volkswagen group, attempts to prevent the French $\mathrm{EDF}^{10}$ from becoming majority shareholder in the electricity group $\mathrm{EnBW}^{11}$ (T3-C5), or support (against the ruling of the Federal Cartel Office) for Eon's takeover of Ruhrgas to create a German champion, are only some of a long list of public interventions to ensure that domestic firms remain under German control. Of course, such attempts were primarily motivated by electoral considerations rather than an interventionist industrial policy per se. They have been more limited than in France and do not fundamentally question Germany's pro-market stance, but indicate nonetheless that Germany is, in practice, not as liberal as it claims to be (Uterwedde 2009). This dichotomy between the French intervening state and the German enabling state, and the way it is reflected in their respective approach to industrial policy, has led to fundamental misunderstandings, with Germany reproaching its neighbour's 'dirigist', 'colbertist' attitude, whilst France was criticising what was perceived as an inconsistent, even hypocritical German attitude. These crucial differences and misunderstandings frequently affect intergovernmental co-operation and also hamper bilateral policy action at EU level.

\footnotetext{
9 'Germany plc.': refers to the traditional intertwinement between the financial sector and industry.

${ }^{10}$ Electricité de France.

${ }^{11}$ Energie Baden-Württemberg
} 


\section{Classifying Inter-firm Linkages}

In the light of diverging industrial policy conceptions rooted in the respective economic traditions of the French state directed and the German state induced $\mathrm{VoC}$, we now need to examine how the respective intervening or enabling role played by the state in these two continental economic models impacts upon state-induced Franco-German corporate alliances. To do this, this paper investigates the most emblematic cases of cross-border linkages between German and French companies in which at least one of the two states concerned has been involved, either as a shareholder, or as a pro-active actor aiming to lead or influence the shaping of such groupings. The research examines a record of all inter-firm linkages established between French and German companies across public and private sectors which have been influenced by state intervention in the last 30 years. Secondary data was collected from a combination of sources ranging from official French and German registers of enterprises $^{12}$ to various official reports, the French and German economic press, library archives and companies' websites in order to draw the most accurate database as well as specific information in each case with regard to government intervention. 35 cases were identified and classified into four distinct categories (see appendices). Whilst many cases are firm-specific, some are sector-specific and therefore comprise several linkages. Indeed, in some cases like the creation of EADS (T1-A1), the merger was in effect the consolidation of numerous pre-existing industrial partnerships ${ }^{13}$ in which French, German and sometimes other European companies were involved.

\footnotetext{
${ }^{12}$ In particular www.unternehmensregister.de and www.journal-officiel.gouv.fr

${ }^{13}$ Airbus, Eurocopter, Ariane
} 
Table 1 groups together 14 cases of M\&As involving French and German firms conducted with direct or indirect state intervention. Table 2 comprises 5 cases of state-led joint ventures (JV) between French and German firms. Table 3 lists up 8 cases of failed state-led attempts to initiate strategic alliances (mergers, JVs), including co-operative alliances ending abruptly or measures taken by France or Germany to prevent a company from the partner country from taking control of a domestic company. Finally, Table 4 details 9 cases of major state-led joint research and development $(\mathrm{R} \& \mathrm{D})$ projects involving firms, research institutions and laboratories from both countries. This classification into four categories allows, firstly, to enhance visibility over various types of state-induced Franco-German inter-firm linkages and the sectors concerned, and to assess which forms of bilateral co-operation are the most frequent. Secondly, analysing this new empirical evidence provides useful insights into the real extent of state-led attempts to promote politically constructed linkages. Thirdly, the database serves as a support in distinguishing alliances where companies concerned or sector consolidation appear to have benefited from state involvement from linkages hampered by inter-state rivalries. Finally, it allows us to evaluate whether a willingness to co-operate proactively in grouping together companies can, in itself, overcome deeply-rooted diverging conceptions of the role played by states in shaping industrial policies.

Certain types of inter-firm linkages, i.e. M\&As, JVs, capital participations and co-operative R\&D projects provide an appropriate focus for this research, as they reflect strategic alliances, whereas other forms of more commercially based contractual arrangements (licensing, franchising) have been left aside. Greenfield investments carried out by French or German enterprises to set up a subsidiary in the neighbouring country have also been left aside since they do not correspond to the definition of an inter-firm linkage, i.e. a contractual (co-operative or control-based) agreement between two firms (Urban et al. 2000). Only one 
major greenfield investment in 1991 in East Germany (T1-A2) is included in the study since it was negotiated at the highest political level and generated linkages between several major French and German firms. One problem encountered in the classification process was to assess whether state influence was direct or underlying. Indeed, the presence of public shares in a company's capital does not preclude that a state dictated an acquisition or a capital participation in the neighbouring country, nor does it indicate that a state was pro-active in launching a JV. Moreover, whilst state control does not necessarily imply state-led intervention, state intervention can also take place when a company is neither state-owned, nor state-controlled through capital participation, golden shares or votes. Furthermore, for several acquisitions listed in Table 1, there is some uncertainty as to whether direct state intervention actually took place. The mere presence of the state in the capital of some companies will, for instance, be a factor influencing strategic decisions in a sense that accommodates this sometimes cumbersome shareholder. However, in most cases, either the French or the German state (most frequently the first, more episodically the second), or in some cases both, have played a determining role, either by facilitating, encouraging or pushing an M\&A operation, the launch of a JV, a capital participation, a joint R\&D project, or simply by blocking a co-operative alliance, hence preventing potential sector consolidation or strategic business choices.

A first examination of the four tables provides useful indications as to which forms of stateinfluenced Franco-German inter-firm linkages tend to be most frequent. Table 1 presents the largest number of linkages across the Rhine, which are overwhelmingly acquisitions ${ }^{14}$. Table 2 only comprises a limited number of JVs. This indicates that JVs, which suppose that control is shared, are not the preferred means of linking French and German firms together. JVs

\footnotetext{
${ }^{14}$ Sometimes preceded by the establishment of joint ventures (eg. Eurocopter, Airbus, Ariane)
} 
ending in a divorce are compiled in table 3. For instance, Areva and Siemens' former nuclear alliance appears in table $3(\mathrm{~T} 3 / \mathrm{C} 2)$, which provides interesting insights into government failures in attempting to push through Franco-German corporate alliances, and into political attempts to prevent deals. Finally, table 4 highlights more recent attempts to boost joint R\&D projects between French and German companies and research centres.

\section{The most emblematic linkages}

A number of observations can be drawn from these tables. The database provides useful insights into French and German state presence in acquisitions, state involvement in public utilities, state influence on private sector companies, and more generally into inter-state rivalry. Nearer investigation into the most emblematic cases reveals that the difficulties experienced in state-led Franco-German linkages are more frequently caused by industrial nationalism than business-related.

In an acquisition, a dominant firm absorbs a weaker firm, whilst in a JV firms are more equal partners. In a merger, there is usually a dominant partner, whilst 'mergers of equals' are rare. Only one substantial Franco-German merger materialised in 1999 (T1-A1), which brought together, under the aegis of EADS, a number of already existing strategic alliances in aeronautics (Aérospatiale and Deutsche Airbus), defence (Aérospatiale-Matra and Dasa, Eurocopter) and space (Astrium and Ariane). The fact that state-led Franco-German interfirm linkages count more acquisitions than mergers or JVs is a clear indication of the difficulties to share power, which shows that the issue of control is politically sensitive in bilateral industrial co-operations. Sectors concerned by acquisitions are primarily banking, 
insurance, consultancy, engineering, postal services, and energy utilities, to which we need to add the Leuna oil refinery greenfield investment and the linked acquisition of the Minol petrol station network (T1-A2). In many cases (particularly T1-A1/2/11/14), political involvement was a determining factor leading to the acquisition. In some, French state presence in the capital of the 'predator' has exerted indirect political pressure on strategic choices (T1-A3/4/5/6/7/8/9/11/14). In a few remaining cases, it is difficult to ascertain whether state presence in the capital of one of the businesses involved played an indirect role in the acquisition. These cross-border acquisitions show nonetheless a substantial imbalance between French and German state presence, with much more frequent incidence of acquisitions of German firms by state-owned French companies, and only two records of acquisitions where the dominant partner is a state-owned German company, Deutsche Post (T1-A12), or a former German public utility with still a minority public stake, Deutsche Telekom (T1-A13). There is, however, no conclusive evidence that either of these acquisitions in France were the outcome of German political interference. The acquisition by German energy provider Eon of EDF's equity interest in Graninge (T1-A10), which allowed EDF to pursue the rationalisation of its foreign operations and Eon to become majority shareholder of the fourth largest Swedish electricity company, is less relevant for this study. Interestingly, the imbalance between takeovers of German firms by French state-owned companies and takeovers of French firms by German companies in which the state has a stake is also reflected in acquisition patterns of private French and German companies [Undisclosed 2006]. Indeed, a higher number of private French enterprises, compared to their German competitors, resort to acquisitions when crossing the Rhine. This is to be attributed, on the German corporate side, to a more co-operative logic with higher propensity to look for co-operative arrangements, and to a French market entry mode looking more often for control. 
The imbalance between French and German state-owned or state-influenced companies involved in cross-border linkages is also due to the presence in France of a larger statecontrolled sector than in Germany. This is particularly noticeable among public utilities. The 1998 liberalisation of the German energy market opened up entry opportunities for foreign utilities, which French state-owned operators EDF and GDF were swift to seize (T1-A8, T3C5/8), though with mixed long-term success. The geographical proximity of the largest energy market in Europe was from an early stage a strong incentive for French public utilities to acquire equity investment in Germany. The fact that the French pace of public service liberalisation was slower allowed French energy giants, until recently, to remain sheltered from competition on their home market whilst expanding on liberalised markets, generating per se asymmetrical market distortions. Their expansion strategies have not only been conducted through acquisitions, but also through initial capital participations followed by gradual consolidation of their shareholding position, as a more discreet way of penetrating German local providers weary of their independence. However, neither EDF, nor GDF have been able to use their stakes in German utilities as a springboard. Apart from some limited success in gaining equity investment in several East German communal energy suppliers, GDF has so far not been able to gain a foothold in Germany (T3-C8). Its attempt to acquire half of $\mathrm{SWL}^{15}$ was turned down by a local referendum rejecting massively the French operator, showing hostility on the part of the local German population. Another recent bid by GDF to acquire a 26 percent stake in $\mathrm{EWE}^{16}$ was beaten by a higher offer from EDF. With this operation, EDF provisionally consolidated its position of third energy producer and supplier in Germany, largely thanks to having gradually raised its share in the capital of EnBW to 45 percent. However, further progression was blocked by EnBW's other major

\footnotetext{
${ }^{15}$ Stadtwerke Leizpig

${ }^{16}$ Energieversorgung Weser-Ems
} 
shareholder, the communal company $\mathrm{OEW}^{17}$, keen to prevent EDF from seizeing majority control, leading in 2010 to EDF's withdrawal from EnBW (T3-C5). These cases are symptomatic for German resistance to the expansion strategies of French groups and lack of reciprocity in market access. Reluctance to let state-owned French groups take control of German utilities is caused not solely by the perception that French industrial policy pursues 'politicised' aims and is more concerned about strengthening French champions than European ones. It also illustrates popular preference for German utilities remaining under German control. In addition, whilst capital participations of French state-controlled companies in German firms concern essentially public sector investments into utilities, there is no example of a state-controlled German firm with participations in the capital of French companies, confirming once again a fundamental difference between the two countries in terms of direct government intervention.

Moreover, it is significant that French government intervention stretches far beyond the remit of state-owned domestic companies. The private corporate sector is also affected, as illustrated by the takeover in 2004 of the Franco-German private pharmaceutical company Aventis by its (also private) French-based smaller competitor Sanofi-Synthélabo (T1-A11): the French political establishment was instrumental in encouraging Sanofi's hostile bid and deterring the Swiss Novartis from acting as the 'white knight'. Cohen and Pisani-Ferry (2005) note that, since the French state had no control of any legal deterrent or financial instrument to dictate its will, the sole tool available to influence Novartis or Aventis was to use political pressure. The outcome of this highly political takeover suggests, in this instance, that this weapon was used very effectively. Interestingly. whilst political manoeuvre allowed the home country of Pasteur and Curie to remain present amongst the 'top ten' of the

\footnotetext{
${ }^{17}$ Oberschwäbische Elektrizitätswerke
} 
pharmaceutical league, the name Hoechst, one of the flagships of post-war German chemical giants and main protagonist of the Franco-German Aventis merger in 2000, was wiped out from the list of major German pharmaceutical companies, raising strong doubts in Germany about the pertinence of developing European champions with a Franco-German foundation.

Furthermore, the list of French state-controlled acquisitions of German businesses is not as extensive as might have been expected from German media's frequent witch-hunting against French 'colbertism'. Whereas acquisitions outside the remit of state control are numerous and tend to be the preferred entry mode for most French and German companies investing in the neighbouring country (Trouille 2006), state-led acquisitions appear, in comparison, to be relatively limited and restricted to a few sectors. The importance and traumatic impact caused by the aforementioned Aventis takeover, in which the 'pharmacy of the world', Germany, lost its massive champion, Hoechst, to a foreign predator, should not be underestimated. The negative perception created by French state-owned energy companies, taking advantage of early liberalisation in German electricity and gas utilities to 'shop' in Germany whilst these were still protected at home from European competition and foreign takeovers, should not be played down either. However, the number of acquisitions taking place between French and German private companies is considerably higher than the relatively limited numbers of German firms taken over by state-owned French firms. This indicates that a claim, which has been frequently referred to in the German press, 'When a German and a French company come together, it normally becomes a French company ${ }^{18}$ may not be fully justified. Suspicions remain, nonetheless, valid when considering state-led acquisitions in activities regarded as strategic.

${ }^{18}$ Wolfgang Münchau, in the Financial Times Deutschland, 10.10.2006 
EADS, sole substantial merger of French and German companies, deserves attention since it has been subject of serious inter-state rivalries (Barmeyer and Mayrhofer 2008). Airbus, in particular, which represents nearly two thirds of the company's turnover, was from the outset a joint state-directed attempt to create a 'merger of equals' between French and German aircraft companies. In sensitive industries like aeronautics, defence and space, where jobs, know-how and national interests are at stake, ensuring that a politically constructed merger is carried out on 'equal' terms was for both French and German political leaders an absolute precondition for it to materialise. However, in sectors perceived as strategic, the perfect fit to satisfy in every respect this critical political requirement whilst at the same time making full sense of a merger in business terms simply does not exist. Companies differ in size, turnover, specialisation and technological know-how. Attempting to bind together two firms whilst preserving a sensitive 'national' balance can pave the ground for managerial tensions and shareholder difficulties, as has been the case for EADS since its inception. More than a decade after having been launched, EADS remains an artificial construct regularly shaken by internal power struggles. The company has two headquarters. France and Germany each control 22.36 percent of the company, Paris through SOGEADE ${ }^{19}$, Berlin indirectly through Daimler, the main German private shareholder ${ }^{20}$. Issues of control tend to dominate hidden agendas on both sides, with Berlin aiming to rebuild its post-war aerospace industry as a long-term strategy, and Paris struggling to prevent that the German side gets the upper hand in Airbus. Berlin acquired an indirect stake to counterbalance Daimler's partial withdrawal and prevent the Franco-German shareholding balance from shifting in France's favour. Notwithstanding this, EADS remains the most impressive collaborative industrial achievement in Europe, but it is faced with a number of deep-rooted challenges, alongside

\footnotetext{
${ }^{19}$ Société de Gestion de l'Aéronautique, de la Défense et de l'Espace, a French holding company jointly owned by the French government and the Lagardère Group.

${ }^{20}$ In addition, SEPI (Sociedad Estatal de Participaciones Industriales), a Spanish state holding company, owns 5.44 percent of EADS.
} 
which an unfavourable euro/dollar exchange rate, is only one of many handicaps. It is an integrated company in legal, but not in operational terms, which may be too big to fail but suffers from a shareholder crisis and needs to overcome tenacious national divisions between as well as within plants scattered throughout Europe. From 2008 until 2012, good progress was made towards overcoming internal national conflicts. However, in October 2012, a proposed tie-up of EADS and Europe's largest defence group $\mathrm{BAE}^{21}$ which would have created a world champion in aeronautics and defence was rejected by the Germany government. The decision was dictated by political considerations in a context of forthcoming state elections in Bavaria and of fears of possible job losses. These may not have been the sole motives for Germany, which was not prepared to reduce its influence in EADS' shareholding at a time when the state-owned development agency $\mathrm{KfW}^{22}$ was planning to buy out Daimler's stake. In addition, eight years after the hostile French takeover of Aventis, Germany remained too suspicious of French industrial interventionism to reduce its influence in EADS.

Let us now examine database information on JVs. Here again, interesting findings can be drawn from analysing the collected data. First, we note that, contrary to the numerous Franco-German JVs set up in the private sector in the last decades, there is only a limited number of JVs involving state-owned companies and in which the German or the French state, ot both, have been instrumental. But sectors concerned are as diverse as steel (T2-B1), media and culture with the Franco-German cultural TV channel ARTE (T2-B2), aeronautics (now part of EADS, T1-A1), gas (T2-B4), rail transportation with co-operations between French and German historical railway operators $\mathrm{SNCF}^{23}$ and $\mathrm{DB}^{24}$ (T2-B3/5), and nuclear

\footnotetext{
${ }^{21}$ British Aerospace

${ }^{22}$ Kreditanstalt für Wiederaufbau

${ }^{23}$ Société nationale des chemins de fer

${ }^{24}$ Deutsche Bahn
} 
energy co-operation between Areva and Siemens until 2009 (T3-C2). With JVs being the second preferred entry mode into the neighbour's market for French and German private companies after acquisitions (Trouille 2006), it is once again surprising to note the low number of state-led Franco-German JVs. This is mainly due to the difficulties that the two parties experience when it comes to sharing assets, jobs, know-how and control. Looking into failed attempts to promote state-led strategic alliances or to prevent M\&As between stateowned French and German firms (T3) will provide further insights.

Second, we note that most co-enterprises listed here are based on equal participations between French and German partner companies (where at least one of each partner involved is partly state-owned), with the notable exception of nuclear energy co-operation, in which Siemens' share of the Areva NP ${ }^{25}$ JV with Areva (T3-C2) was limited to 34\%, and which came to an abrupt end in 2009.

Third, there is no state-led JV with dominant German stake. This, once again, reflects a contrast between pro-active, interventionist French stance and German reluctance to interfere directly in business affairs. This also reflects the fact that the German political establishment does not have the same tools, political tradition and legitimacy as its French counterparts at its disposal to interfere with business goals and carry out pro-active industrial policies.

Whist the first two databtables examine different market entry modes of state-led companies, the third concerns government failures in attempting to push through Franco-German corporate alliances, and political attempts to prevent certain deals. This provides additional

${ }^{25}$ NP: Nuclear Power. 
insights into the sometimes very activistic role played by states in shaping strategic alliances. A number of cases reflect recurrent tensions between politics and markets.

The co-operation in the 1990s between state-owned telecommunications operators $\mathrm{FT}^{26}$ and $\mathrm{DT}^{27}$ was emblematic of a jointly decided state-enforced rapprochement (T3-C1) with joint subsidiaries and cross-participations. However, the partnership broke up in the wave of liberalisation. This case exemplifies strategies of competing telecommunications giants corresponding to a business logic geared towards external growth but incompatible with political aspirations to create a Franco-German global player. Interestingly, both groups are now coming closer together through a co-operation in $\mathrm{R} \& \mathrm{D}$, a more sensible move when considering mounting pressures to innovate in high-technology sectors.

Plans to consolidate Europe's naval sector by creating a 'Maritime EADS' (T3-C6) also ended up abruptly due to lack of trust (Becker and Marx 2005). Sector consolidation in the sensitive field of defence technology failed due to national concerns not to lose out prerogatives, to remain in control and to prioritise national restructuring before considering further steps. This desire of EU member-state governments to keep control of national defence champions is a major obstacle towards transnational mergers preventing a much needed European-wide reorganisation.

The fate of the Paris-based pan-European stock exchange Euronext is also symptomatic for a lack of Franco-German ambition resulting in a missed opportunity to unify European stock exchanges (T3-C3). Rather than becoming junior partner in a European alliance led by Deutsche Börse, Euronext broke up merger negotiations with in 2006 and opted, with French

\footnotetext{
${ }^{26}$ France Télécom.

${ }^{27}$ Deutsche Telekom.
} 
political backing, for a transatlantic solution under the aegis of $\mathrm{NYSE}^{28}$, rejecting a substantially higher offer from Frankfurt alongside attractive concessions. Interestingly, the two most instrumental member states in launching $\mathrm{EMU}^{29}$ were unable to overcome divisions and build a Eurozone-wide stock exchange ${ }^{30}$.

The Alstom/Siemens case (T3-C7) also deserves attention. French state aid aimed at safeguarding a French 'national jewel'. A rescue deal comprising temporary 31 percent recapitalisation negotiated with Brussels aimed at redressing Alstom's financial situation whilst thwarting Siemens' chances of acquiring the troubled engineering group's key assets on the cheap. This government intervention took place shortly after the Sanofi-Synthélabo's hostile bid on Aventis (T1-A11). The German government's hopes that an Alstom deal favourable to Siemens would counterbalance the Aventis takeover ended in disillusion.

Two other cases discussed earlier, in the nuclear (T3-C2) and energy unility sector (T3-C5) came abruptly to an end in 2009 with Siemens' withdrawal from Areva, and in 2010 with EDF's withdrawal from EnBW, each time because they were prevented from increasing their stake. These were the last two of a series of significant corporate alliances, all of which failed one after the other, with the notable exception of EADS.

Another illustration of the struggle to launch joint co-operative projects is the railways, a domain in which both countries aim to expand within a liberalised European rail market. However, competition between SNCF and DB has sharply intensified, although policy advisers on both sides have for decades made a compelling business case for merging the two state railways to form an Airbus equivalent in rail transportation. Contrary to most other areas

\footnotetext{
${ }^{28}$ New York Stock Exchange.

${ }^{29}$ Economic and Monetary Union.

${ }^{30}$ At the time of writing, NYSE-Euronext and Deutsche Börse are planning to merge.
} 
there French and German companies are competitors on the same market segments, both national operators complement each other, DB with a comparative advantage in freight transport, and SNCF in passenger transport. However, deep mistrust, worsened by recent competition to expand high-speed train services across the Channel Tunnel, has prevented a deal $^{31}$.

\section{More promising fields of co-operation}

The last table displays relevant insights into recent attempts to boost R\&D projects between French and German companies and research centres as a more promising way of encouraging industrial actors to co-operate for mutual benefit in terms of scale economies, cost and risk sharing, and joint know-how. The Mobilising Programmes for Industrial Innovation of the $\mathrm{AII}^{32}$ (now part of OSEO ${ }^{33}$ ) launched in France on Beffa's proposal (2005) were an attempt to make up for weaknesses in French research, industrial development and innovation effort (Trouille and Uterwedde 2008). The agency's mission was to initiate and support large-scale high-tech industrial projects conceived by a multi-actor partnership of large and small business and private and public R\&D organisations under a large company's leadership. Two AII-selected projects are Franco-German: NeoVal (T4-D3), which brings together Siemens Transportation Systems and Lohr Industrie, and Iseult/Inumac (T4-D4), jointly led by Siemens and Guerbet. Such co-operative initiatives make more sense and generate less conflictual supranational co-operations. They are, however, not exempt of tensions: the Quaero project of an Internet research engine, also put forward by the AII, suffered from rivalries between the French and German companies involved and was eventually split into

\footnotetext{
${ }^{31}$ In any event, such a deal would have to be endorsed by the European competition auhtorities.

${ }^{32}$ Agency for Industrial Innovation

${ }^{33}$ OSEO (from the French 'oser haut': to target high)
} 
two distinct national projects. This 'fight of dwarves' questioned the wisdom of trying to compete against Google with inadequate financial means.

Galileo (T4-D2) is yet another example of the awkwardness of launching a supranational project when it comes to dividing costs and benefits between national firms. This ambitious $€ 3.4$ bn global navigation satellite system, due to be operational by 2013 , is currently Europe's most important technological and industrial project. However, even there, France and Germany have argued about issues of supremacy, control centres, costs and contracts. Germany was eager to ensure it would win a share of procurement contracts proportionate to its EU-budget contributions, but feared that most competitive tenders, under EU rules, would be allocated to non-German space companies. The project nearly failed until the December 2007 EU Summit agreed to inject EU public funding to make the project viable, and to divide it into six slices with separate calls for tenders and companies only allowed to lead in two areas.

Other interesting examples of technological inter-firm co-operations include alliances in the automotive industry, between Daimler and Renault Nissan (T4-D6), and between BMW and Peugeot, to develop new engines and electric vehicles. Also worth mentioning is the joint initiative of the French industrial innovation agency OSEO and KfW to launch EuroQuity in 2011 (T4-D8), in order to boost bilateral co-operation on high technology projects.

Such recent initiatives indicate that Franco-German industrial co-operation may have drawn consequences from past mistakes. It has turned the page of political rivalries that led to the failure of most Franco-German champions and is now pursuing a different path, looking for increased efficiency and geared towards innovation in future technologies. 


\section{Conclusions}

Encouraged, or actively pushed forward, by governments, French-German inter-firm linkages were presented sometimes as a logical consequence of the special political relationship uniting the two countries since five decades, sometimes as the cornerstone of a Europeanwide industrial policy. However, mistrust and rivalries have questioned the principle of nurturing privileged bilateral industrial partnerships. They indicate that state-influenced cross-border industrial co-operations, far from being a 'natural' development of FrenchGerman relations, constitute a delicate exercise, especially in key areas of national sovereignty, and that, beyond official rhetoric on promoting supranational 'champions' with a Franco-German setting, France and Germany have remained fundamentally divided by their own industrial nationalism. Antagonistic national divisions have plagued corporate alliances. They highlight the difficulty to overcome inter-state rivalries despite a background of increased economic interdependence, and they question the appropriateness of enforcing cooperations between firms often competing in similar market segments. In most aforementioned cases, the issue of control has proved to be a major concern for French and German decision makers. Failed or aborted state-led linkages were caused by obstructive state interference. State-sponsored initiatives have been instrumental in launching certain large-scale bilateral or multinational alliances which would, otherwise, never have materialised under strict market conditions, especially in aircraft, defence and space. But this remains limited to sectors where strategic considerations justify public intervention. Even in successfully implemented alliances, states frequently act as troublemakers tempted to place political choices above business logic at the cost of EU competition and single market rules. 
States rarely have the business understanding required to identify and pursue trends better than market players. The appropriateness of an alliance must be determined by commercial, financial and business criteria rather than dictated by political agendas. National obstructions are also a major obstacle to the furthering of market integration, as attested by the fact that nearly two decades after its inception, the Single Market has only generated very few truly European firms. State-sponsored support for R\&D projects beyond the national framework is nonetheless a promising development, depending on the pertinence of the selected projects and subject to state aid being compatible with EU rules.

Against this background, this empirical analysis of French and German patterns of public intervention into the expansion strategies of home companies has revealed substantial differences in the way France and Germany organise their own government-industry relations. This reflects a long-standing cultural divide between Berlin and Paris about state interventionism, traditionally reflected in different traditions corresponding to two VoCs similar in their conception of the social market economy, but dissimilar in terms of the role played by the state in the national economy. This discrepancy is particularly apparent in two distinct conceptions of industrial policy. On one side, certain home companies are protected against foreign investors, while on the other it is claimed that markets are more open to investors and averse to political intervention. However, this picture no longer fully corresponds to reality. Despite clear resurgence of state interventionism during Sarkozy's presidency, French state-directed capitalism has undergone considerable change under the combined pressures of European integration and globalisation. The state has retreated significantly from its traditional role, and France has a more 'liberal' economy than is generally perceived (Trouille and Uterwedde 2008). Traditional French industrial policy model based on rigid, state-led, centralist top-down model of industrial development was only 
possible as long as businesses, funding and public orders were all under state control. With economic liberalisation and EU regulation, this is no longer possible, even though old, ingrained interventionist habits die hard. In contrast, Germany has traditionally been a fervent proponent of market openness and corporate autonomy, showing strong reluctance towards direct political intervention to preserve 'national' interests. In practice, however, more subtle forms of industrial policy are exercised at regional and local level, as illustrated by local opposition to French energy companies. In addition, until recently historic bonds between banking and industry were protecting German companies against foreign takeovers. The shock caused in 2002 by Vodafone's takeover of Mannesmann, followed by a debate on sovereign wealth funds revealed increasing sensitivity in German public opinion about the risk of losing control on national assets. Respective French and German attitudes towards industrial policy, therefore, are less contradictory than would appear at first glance. French discourse on economic patriotism is more a matter of rhetoric, whose function is to reassure an electorate lacking confidence in the benefits of economic globalisation, rather than an established protectionist policy in its own right. Conversely, Germany's rhetoric on free markets often conceals more or less hidden interventionist practices. Despite apparently opposed, historically grounded attitudes towards the role of the state in government-industry relations and, more generally, in the economy, the two main protagonists of a 'continental' European capitalism are not as fundamentally different as is generally assumed.

This research and its classification of inter-firm linkages have allowed us to test this paper's initial assumption that a declared willingness to co-operate, however strong the determination may claim to be, is not sufficient to resolve deeply-rooted differences in conceptions of the role of the state and in the interpretation of what industrial policy entails. A joint ambition can only be fulfilled if it is backed up by a clear consensus on joint industrial policy aims, 
which supposes shared efforts to resist the sirens of industrial nationalism. Only by transcending their industrial nationalism and, arguably, by Europeanising the notion of economic patriotism, will France, Germany and other EU member states be able to launch the kind of ambitious large-scale cross-national industrial projects that the EU needs to consolidate its position in the knowledge economy and remain a key actor in the wave of economic globalisation.

8,204 words

\section{REFERENCES}

Artus, P. (ed) (2009) L'Allemagne, un modèle pour la France? Les Cahiers, Le Cercle des économistes, Presses Universitaires de France.

Atherton, A. (2006) Should governments be stimulating start-ups ? An assessment of the scope for public intervention in new venture formation. Environment and Planning $C$ : Government and Policy 24(1) 21-36.

Barmeyer, C. and Mayrhofer, U. (2008) The Contribution of Intercultural Management to the Success of International Mergers and Acquisitions: An Analysis of the EADS Group, International Business Review, 17(1) 28-38.

Becker, P. and Marx, S. (2005) Europäische Champions - Aufgabe europäischer Industriepolitik? Fallbeispiel maritime Industrie, working paper, research group on EU Integration, Stiftung Wissenschaft und Politik, Deutsches Institut für Internationale Politik und Sicherheit, Berlin, February 1.

Beffa, J.-L. (2005) Renewing Industrial Policy. Report submitted to the French president on 15.01.05, Paris, La documentation française.

Bennett, R. (2008) SME policy support in Britain since the 1990s: what have we learnt?" Environment and Planning C: Government and Policy 26(2) 375-397.

Callaghan, H. (2008) How Multilevel Governance affects the Clash of Capitalism/ Max Plank Institute for the Study of Societies, MPIFG Discussion Paper 08/5.

Cohen, E. (1992) Le colbertisme 'high tech'. Economie des télécom et du GrandProjet. Paris, Hachette.

Cohen, E. and Pisani-Ferry (2005), J. Economic Institutions and Policies in the US and the EU: Convergence or Divergence? Paper prepared for the Second Annual Berkeley-Vienna Conference on US and European Economies in Comparative Perspective, September. 
Colletis, G. and Levet, J.-L. (1997) Quelle politique pour l'industrie française? Paris, La documentation française.

Colletis, G., Levet, J.-L. and Uterwedde, H. (eds.) (2001) Compétitivité globale: une perspective franco-allemande. La documentation française.

COM (2010) 608 final : Single Market Act for a highly competitive social market economy, Brussels, 27 October.

Cromme, G. (2005) Politique industrielle: l'action commune est possible, Revue des deux mondes (October-November) 10-11, 177-186.

Dyson, K. and Goetz, K. (eds) (2003) Germany, Europe and the Politics of Constraint. Oxford: Oxford University Press.

Gaudard, J.-P. (2005) Le mal industriel français. En finir avec l'acharnement de l'Etat. Paris, Bourin Editeur.

Hall, P.A. and Soskice, D. (eds.) (2001) 'Introduction', Varieties of Capitalism. The Institutional Foundations of Comparative Institutional Advantage. Oxford: Oxford University Press, 1-68.

Hancké, B., Rhodes, M. and Thatcher, M. (eds) (2007) Beyond Varieties of Capitalism. Conflict, Contradictions and Complementarities in the European Economy. Oxford: Oxford University Press.

Hayward, J. (ed) (1995) Industrial enterprise and European integration - From National to International Champions in Western Europe. Nuffield European Studies, Oxford: Oxford University Press.

Izraelevicz, E. (1999) Le capitalisme zinzin, Paris, Grasset.

Landier, A. and Thesmar, D. (2005) Quel patriotisme au XXIe siècle? Amicus Curiae, Briefing paper, Institut Montaigne, December.

Levet, J.-L. (2000) 'La nationalité de l'entreprise: un enjeu pour une ambition industrielle européenne', Politiques industrielles pour l'Europe, report of the Conseil d'analyse économique, Paris, La documentation française.

Levet, J.-L. (2005) Les politiques industrielles dans le monde: illustrations, enseignements et perspectives'. In Fontagné, L. and Lorenzi, J.-H. (eds) Désindustrialisation, délocalisations. Conseil d'Analyse Economique, Paris, La documentation française, 315-56.

Maclean, M. (2002) Economic Management and French Business. From de Gaulle to Chirac. Palgrave Macmillan.

Mayrhofer, U. (2001) Les rapprochements d'entreprises: une nouvelle logique stratégique? Bern, Peter Lang.

Mayrhofer, U. (2004) The Influence of National Origin and Uncertainty of the Choice between Cooperation and Merger-Acquisition: An Analysis of French and German Firms. International Business Review, Vol.13 No1, 83-99.

Menu, S. (2012) The role of cluster policy on leadership: evidence from two Pôles de compétitivité. Environment and Planning C : Government and Policy 30(5) 816-34. 
Monti, M. (2010) A New Strategy for the Single Market. Report to the President of the European Commission, Brussels, 9 May 2010.

Mosconi, F. (2006) The Age of 'European Champions'. A New Chance for EU Industrial Policy, The European Union Review, 11:1, 29-59.

Schmidt, A. V. (2002) The Futures of European Capitalism, New-York, Oxford University Press.

Schmidt, A. V. (2003) French Capitalism Transformed, yet still a Third Variety of Capitalism. Economy and Society 32(4), November, 526-554.

Schmidt, A. V. (2008) European Political Economy: Labor Out, State Back In, Firm to the Fore. West European Politics 31 (1-2), 302-320.

Schmidt, A. V. (2009) Putting the Political Back into Political Economy by Bringing the State Back Yet Again. World Politics, 61:516-546.

Seabright, P. (2005) National and European Champions - Burden or Blessing, CES-Ifo Bulletin, 6(2) $52-57$.

Sternberg, R., Kiese, M. and Stockinger, D. (2010) Cluster policies in the US and Germany: varieties of capitalism perspective on two high-tech states. Environment and Planning C: Government and Policy 28(6) 1063-82.

Streeck, W. (1996) Le capitalisme allemand existe-t-il? A-t-il des chances de survivre? In Crouch, C. and Streeck, W. (eds) Les capitalismes en Europe. Paris, La Découverte, 47-75.

Trouille, J.-M. (2006) Die Kooperation deutscher und französischer Unternehmen zwischen Konkurrenz und Partnerschaften, Dokumente - Zeitschrift für den deutsch-französischen Dialog, Bonn, 62:1, 31-42.

Trouille, J.-M. (2007) Re-Inventing Industrial Policy in the EU: A Franco-German Approach. WestEuropean Politics Vol. 3, May, London, Routledge, 502-523.

Trouille, J.-M. and Uterwedde, H. (2008) From Industrial Policy to Competitiveness Policy? The New French Strategy. In Maclean, M. and Szarka, J. France on the World Stage. Nation State Strategies in the Global Era, London, Palgrave Macmillan, 162-180.

Trouille, J.-M. and Uterwedde, H. (2013) Frankreich, Deutschland und die europäische Wirtschaftspolitik: Kooperation mit Hindernissen. Frankreich Jahrbuch, Deutsch-französische Beziehungen, Deutsch-französisches Institut / Springer VS, 127-144.

Urban, S., Mayrhofer, U. and Nanopoulos, P. (2000) Inter-firm Linkages: The European Experience. In Tayeb, M. (ed), International Collaborative Partnerships, London, Macmillan.

Uterwedde, H. (2009) Politique industrielle: heurts et malheurs de la coopération franco-allemande. Annuaire Français des Relations Internationales, Vol. 10, Brussels, Bruylant, 563-577.

Véron, N. (2006) Farewell National Champions, Bruegel Policy Brief No2006/04, Brussels.

Wruuck, P. (2006) Economic Patriotism. New Game in Industrial Policy? Deutsche Bank Research, EU Monitor 35, June 14. 


\section{APPENDIX SECTION}

\section{Table 1: M\&A activity involving French and German firms with direct of indirect state intervention}

N.B.: In takeovers the dominant partner is underlined. In the case of a merger of equals no company name is underlined.

Source: Compiled by author

\begin{tabular}{|c|c|c|c|c|}
\hline Classification & Date & French company & German company & Sector/Outcome \\
\hline \multirow[t]{6}{*}{ A1 } & 12.1970 & Aérospatiale & Deutsche Airbus & $\begin{array}{l}\text { Launch of Economic Interest Group Airbus } \\
\text { Industries. }\end{array}$ \\
\hline & 1992 & Aérospatiale & Dasa & Launch of Eurocopter. \\
\hline & 1996 & & & $\begin{array}{l}\text { Creation of EMS (European Missile Systems) and } \\
\text { EMI (European Satellite Industry). }\end{array}$ \\
\hline & 12.1999 & Aérospatiale-Matra & Dasa & $\begin{array}{l}\text { Announcement of EADS merger (July 2000). All } \\
\text { existing co-operative projects (Eurocopter, } \\
\text { Airbus, Ariane...) are integrated into EADS. }\end{array}$ \\
\hline & 2006 & $\begin{array}{l}\text { EADS } \\
\text { (French-German-Spanish) }\end{array}$ & ThyssenKrupp & $\begin{array}{l}\text { ThyssenKrupp }(60 \%) \text { and EADS ( } 40 \%) \text { purchase } \\
\text { sonar specialist Atlas Elektronik. Germany } \\
\text { invoked national security grounds to decline } \\
\text { substantially higher offer by Thales (France). }\end{array}$ \\
\hline & 10.2012 & EADS & EADS & $\begin{array}{l}\text { A proposed merger between EADS and BAE is } \\
\text { turned down by the German government. }\end{array}$ \\
\hline A2 & 1991 & $\frac{\text { Elf Aquitaine }}{\text { (privatized in 1994) }}$ & $\begin{array}{l}\text { Treuhandanstalt (German } \\
\text { government agency (1990-94) } \\
\text { responsible for privatizing East } \\
\text { German combinates) } \\
\end{array}$ & $\begin{array}{l}\text { Major investment negotiated at highest state level: } \\
\text { construction of Leuna oil refinery. In return, Elf } \\
\text { takes over Minol service station network in new } \\
\text { Federal States. }\end{array}$ \\
\hline \multirow[t]{2}{*}{ A3 } & 12.1992 & Crédit Lyonnais & $\begin{array}{l}\text { Bank für Gemeinwirtschaft } \\
\text { (BfG) }\end{array}$ & $\begin{array}{l}\text { Crédit Lyonnais (nationalized in 1945, privatized } \\
\text { in 1999) purchases this major retail bank and } \\
\text { becomes first foreign bank to enter Germany. }\end{array}$ \\
\hline & 10.1999 & & & $\begin{array}{l}\text { Crédit Lyonnais sells BfG to Swedish group SEB } \\
\text { for } \$ 1.7 \mathrm{bn} \text {. }\end{array}$ \\
\hline A4 & 1996 & $\begin{array}{l}\text { UAP (Union des Assurances } \\
\text { de Paris, state-owned in 1993) }\end{array}$ & Colonia Nordstern & $\begin{array}{l}\text { Colonia Nordstern becomes part of UAP, } \\
\text { purchased by AXA a year later. }\end{array}$ \\
\hline \multirow[t]{6}{*}{ A5 } & 1996 & $\begin{array}{l}\text { Scetauroute SA } \\
\text { (re-named Egis in 1997) }\end{array}$ & Dorsch Consult & $\begin{array}{l}\text { Both firms merge their European consultancy } \\
\text { engineering activities. }\end{array}$ \\
\hline & 1997 & $\underline{\text { Egis }}(\mathrm{CGC})$ & Dorsch Consult & $\begin{array}{l}\text { Egis, engineering subsidiary of Caisse des } \\
\text { Dépôts et Consignations (CGC), acquires } \\
\text { Dorsch Consult. }\end{array}$ \\
\hline & 1997 & $\underline{\text { Egis }}$ & Airplan & $\begin{array}{l}\text { Egis acquires } 80 \% \text { of Airplan (Stuttgart) through } \\
\text { Dorsch Consult. }\end{array}$ \\
\hline & 2000 & $\underline{\text { Egis }}$ & wpm Projektmanagement & $\begin{array}{l}\text { Egis acquires } 100 \% \text { of wmp Projektmanagement } \\
\text { (Stuttgart) through Dorsch Consult. }\end{array}$ \\
\hline & 01.2005 & Egis & Dornier Consulting & $\begin{array}{l}\text { Egis sells all wmp Projektmanagement shares to } \\
\text { Dornier Consulting. }\end{array}$ \\
\hline & 09.2005 & Egis & Hoffmann Röder & $\begin{array}{l}\text { Egis sells loss making Dorsch Consult to } \\
\text { Hoffmann Röder. }\end{array}$ \\
\hline A6 & 01.1999 & $\frac{\text { Usinor (now part of Arcelor- }}{\text { Mittal) }}$ & Eko-Hüttenwerk & $\begin{array}{l}\text { Usinor acquires Belgian steel producer Cockerill- } \\
\text { Sambre and its East German subsidiary Eko } \\
\text { Stahlwerk. }\end{array}$ \\
\hline A7 & 12.2000 & $\underline{\text { La Poste }}$ & Deutscher Paketdienst (DPD) & $\begin{array}{l}\text { Government-owned, yet independently operated } \\
\text { French postal service La Poste takes over the } \\
\text { DPD European network by controlling } 84.8 \% \text { of } \\
\text { voting rights and becomes second-largest parcel } \\
\text { operator in Germany. }\end{array}$ \\
\hline A8 & 12.2002 & Gaz de France (GDF) & Preussag Energie & $\begin{array}{l}\text { TUI concentrates activities on tourism and sells } \\
\text { its Energy subsidiary to GDF. }\end{array}$ \\
\hline A9 & 03.2003 & $\begin{array}{l}\text { Louis Dreyfus } \\
\text { Communications SA } \\
\text { (LDCom), now Neuf Cegetel } \\
\text { (privately-owned) } \\
\end{array}$ & $\begin{array}{l}\text { Deutsche Telekom } \\
\text { (State-owned) }\end{array}$ & $\begin{array}{l}\text { German operator DT sells deficit-making French } \\
\text { subsidiary Siris, specialized in landline } \\
\text { connections and services to business, to French } \\
\text { telecoms operator LDCom. }\end{array}$ \\
\hline A10 & 08.2003 & Graninge (EDF) & $\underline{\text { Eon }}$ & $\begin{array}{l}\text { EDF sells its } 36.4 \% \text { of fourth-largest Swedish } \\
\text { electricity supplier to Eon. }\end{array}$ \\
\hline A11 & 06.2004 & $\frac{\text { Sanofi-Synthélabo }}{\text { (privately owned) }}$ & $\begin{array}{l}\text { Aventis (Franco-German, } \\
\text { privately owned) }\end{array}$ & 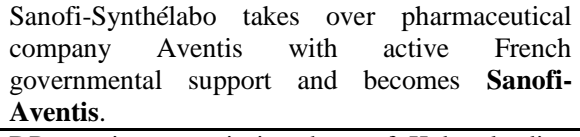 \\
\hline A12 & 12.2004 & Koba & Deutsche Post & $\begin{array}{l}\text { DP acquires a majority share of Koba, leading } \\
\text { specialist in France for direct marketing and mail } \\
\text { solutions. }\end{array}$ \\
\hline
\end{tabular}




\begin{tabular}{|c|c|c|c|c|}
\hline Classification & Date & French company & German company & Sector/Outcome \\
\hline A13 & 02.2005 & T-Online (Lagardère group) & Deutsche Telekom & $\begin{array}{l}\text { DT (in which the German government still held } \\
15.7 \% \text { and another } 14 \% \text { through its KfW bank) } \\
\text { increases gradually its stake in T-Online since } \\
\text { 2000. In } 2005 \text { Lagardère sells its remaining shares } \\
\text { and DT takes majority control. }\end{array}$ \\
\hline A14 & 09.2007 & Areva & Multibrid & $\begin{array}{l}\text { After an unsuccessful bid against Suzlon (India) } \\
\text { to acquire wind power group REPower, of which } \\
\text { it holds } 30 \% \text {, Areva (nuclear sector) purchases } \\
51 \% \text { of offshore wind turbine developer } \\
\text { Multibrid. Prokon Nord retains } 49 \% \text {. }\end{array}$ \\
\hline
\end{tabular}

\section{Table 2: $\quad$ State-led joint ventures (JV) between French and German firms}

N.B.:

When there is equal participation no company name is underlined. The name of the French company is underlined if there is a dominant French stake.

Source: Compiled by author

\begin{tabular}{|c|c|c|c|c|}
\hline Classification & Date & French partner & German partner & Sector/Outcome \\
\hline B1 & 1991 & Usinor-Sacilor & Mannesmann & $\begin{array}{l}\text { French state-owned steelmaker and German steel } \\
\text { giant merge tubing activities and launch a JV for } \\
\text { large-diameter pipe production, Europipe (now } \\
\text { owned by Dillinger Hüttenwerke and Salzgitter } \\
\text { Mannesmann). }\end{array}$ \\
\hline B2 & 05.1991 & La Sept TV Channel & ARD/ZDF & $\begin{array}{l}\text { Mitterrand and Kohl launch Franco-German } \\
\text { cultural channel ARTE (Association Relative à } \\
\text { la Télévision Européenne). }\end{array}$ \\
\hline B3 & 06.1996 & $\underline{\text { SNCF }}$ & $\begin{array}{l}\text { NMBS/SNCB (Belgium), } \\
\text { joined later by DB and } \\
\text { Nederlandse Spoorwegen } \\
\text { (NS) }\end{array}$ & $\begin{array}{l}\text { SNCF and NMBS/SNCB launch international } \\
\text { high-speed train operatorThalys and are } \\
\text { subsequently joined by DB and NS. (SNCF: } \\
62 \% \text {, DB: } 10 \% \text {, NMBS/SNCB: } 28 \% \text { ). Thalys } \\
\text { operates Paris-Cologne services via Brussels. }\end{array}$ \\
\hline B4 & 03.2002 & Gaz de France (GDF) & Ruhrgas & $\begin{array}{l}\text { GDF, Ruhrgas and Gasprom (Russia) purchase } \\
49 \% \text { of SPP (Slovakia). }\end{array}$ \\
\hline B5 & 05.2007 & SNCF & $\overline{\text { DB }}$ & $\begin{array}{l}\text { The state-owned railway operators launch } \\
\text { Rhealys, a 50/50 JV with headquarters in } \\
\text { Sarrebruck, to exploit high-speed trains on Paris- } \\
\text { Francfort and Paris-Stuttgart-Munich lines from } \\
2007 \text { onwards. } \\
\text { To replace Rhealys, SNCF and DB launch Alleo } \\
\text { (Alliance Est-Ouest), a joint consortium based in } \\
\text { Sarrebruck, to operate high-speed tracks on the } \\
\text { new TGV Est (Paris-Frankfurt) line (using } \\
\text { German ICE train sets) and Paris- } \\
\text { Stuttgart/Munich (using French TGV train sets). }\end{array}$ \\
\hline
\end{tabular}

Table 3: Failed attempts to initiate state-led strategic alliances and/or measures to prevent M\&As between French and German firms with a state participation

Source: Compiled by author

\begin{tabular}{|c|c|c|c|c|}
\hline Classification & Dates & French company & German company & Sector/Outcome \\
\hline \multirow[t]{8}{*}{ C1 } & 1987 & France Télécom & Deutsche Telekom & $\begin{array}{l}\text { The two state-owned operators launch joint } \\
\text { subsidiary Eucom. }\end{array}$ \\
\hline & 03.1992 & & & Launch of second subsidiary, Eunetcom. \\
\hline & 12.1993 & & & Launch of Atlas. \\
\hline & 06.1995 & & & $\begin{array}{l}\text { Alliance with US company Sprint: FT and DT } \\
\text { buy 10\% each in Sprint. }\end{array}$ \\
\hline & 01.1996 & & & $\begin{array}{l}\text { Launch of Global One (international services of } \\
\text { business). FT and DT buy 25\% each. }\end{array}$ \\
\hline & 04.1998 & & & $\begin{array}{l}\text { FT, DT and Energis (GB) launch a JV, } \\
\text { MetroHoldings, to expand on the British market. } \\
\text { Energis owns 50\%, FT and DT } 25 \% \text { each. }\end{array}$ \\
\hline & 12.1998 & & & $\begin{array}{l}\text { FT and DT exchange cross-participations ( } 1.8 \% \\
\text { each). }\end{array}$ \\
\hline & 05.1999 & & & The FT/DT alliance ends up abruptly after DT's \\
\hline
\end{tabular}




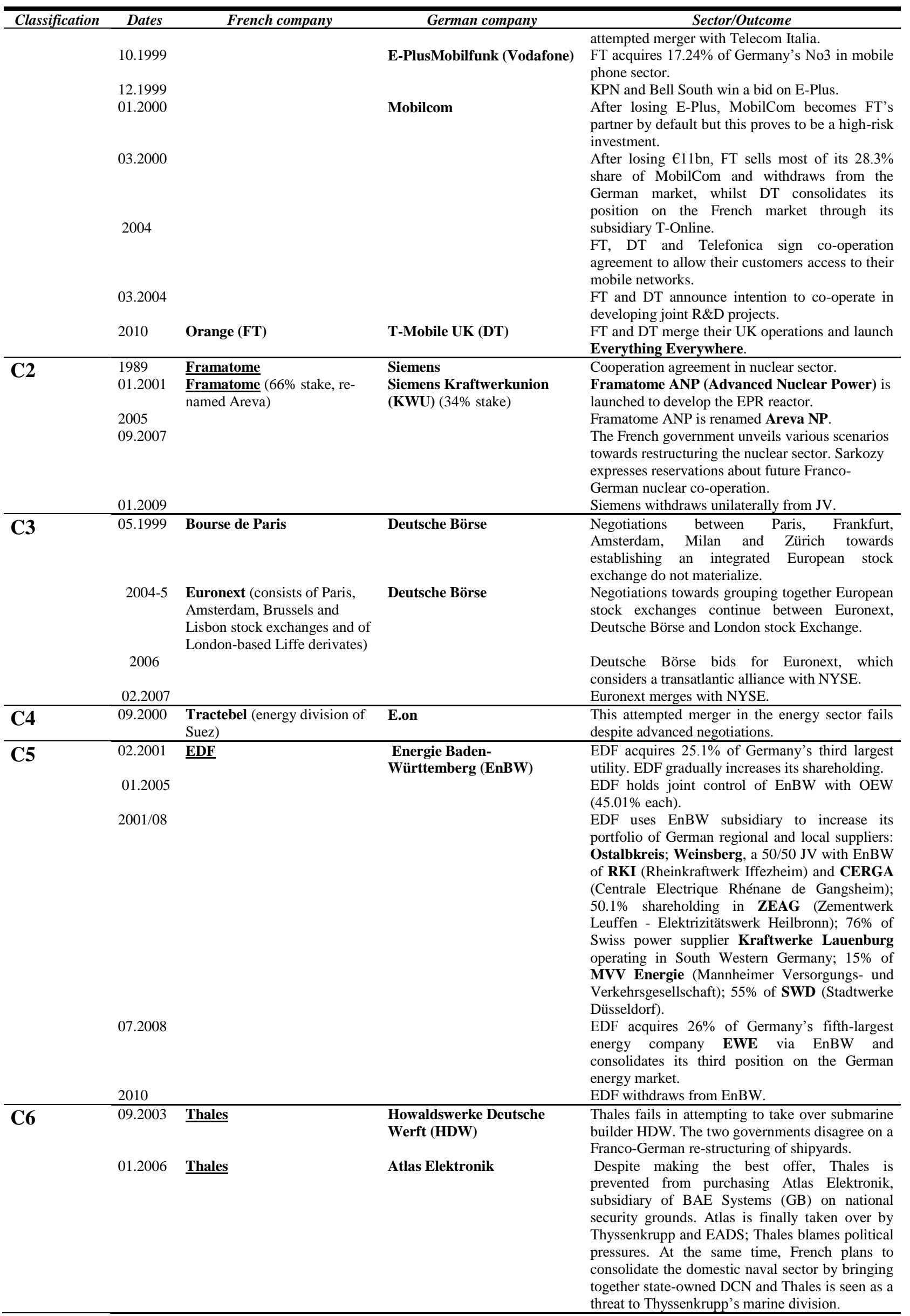




\begin{tabular}{|c|c|c|c|c|}
\hline Classification & Dates & French company & German company & Sector/Outcome \\
\hline C7 & 06.2004 & Alstom & $\underline{\text { Siemens }}$ & $\begin{array}{l}\text { The French government re-capitalises Alstom and } \\
\text { prevents Siemens from acquiring its profitable } \\
\text { activities. }\end{array}$ \\
\hline C8 & 02.2008 & Gaz de France (GDF) & $\begin{array}{l}\text { Gasag (Berliner Gaswerke) } \\
\text { Verbundnetzgas (VNG) } \\
\text { Erdgas Mark } \\
\text { Brandenburg (EBM) }\end{array}$ & $\begin{array}{l}\text { GDF acquires: } \\
-31.6 \% \text { of Berlin gas utility Gasag and shares } \\
\text { control with Bewag; } \\
\text { - Shares of East German utilities VNG }(5 \%) \text { and } \\
\text { EBM }(25.5 \%) \text {. }\end{array}$ \\
\hline & & & SWL (Stadtwerke Leipzig) & $\begin{array}{l}\text { In a referendum organized on } 27.1 .08 \text { the Leipzig } \\
\text { population overwhelmingly rejects GDF's offer to } \\
\text { acquire } 49.9 \% \text { of local electricity provider SWL. }\end{array}$ \\
\hline
\end{tabular}

\section{Table 4: Major state-led joint R\&D projects involving French and German firms, research institutions and laboratories}

Source: Compiled by author

\begin{tabular}{|c|c|c|c|c|c|}
\hline $\begin{array}{l}\text { Classif } \\
\text { ication }\end{array}$ & Date & $\begin{array}{c}\text { Project } \\
\text { Framework }\end{array}$ & $\begin{array}{c}\text { French } \\
\text { companies }\end{array}$ & $\begin{array}{l}\text { German companies, } \\
\text { institutions }\end{array}$ & $\begin{array}{c}\text { Details: funding bodies, type of framework } \\
\text { (cooperative/competitive) }\end{array}$ \\
\hline D1 & 03.2002 & $\begin{array}{l}\text { EIFER } \\
\text { (European } \\
\text { Institute for } \\
\text { Energy } \\
\text { Research) } \\
\end{array}$ & EDF & $\begin{array}{l}\text { University of } \\
\text { Karlsruhe }\end{array}$ & $\begin{array}{l}\text { EDF co-finances research project to develop clean energy } \\
\text { technologies for sustainable development in cities and territories, } \\
\text { with researchers from France, Germany and other countries. }\end{array}$ \\
\hline D2 & 11.2007 & Galileo & $\begin{array}{l}\text { EADS, Thales, } \\
\text { Alcatel }\end{array}$ & $\begin{array}{l}\text { EADS-Astrium, } \\
\text { TeleOp }\end{array}$ & $\begin{array}{l}\text { The private consortium responsible for launching Galileo attempts } \\
\text { to bring together the main European space companies alongside } \\
\text { EADS: Thales and Alcatel (Fr.), TeleOp (Gy.), Finnmeccanica (It.), } \\
\text { Aena and Hispasat (Sp.) and Inmarsat (GB). It is decided to set up } \\
\text { Galileo's headquarters in Toulouse and its control centre in } \\
\text { Oberpfaffenhofen (Munich). } \\
\text { The consortium fails to reach agreement and withdraws from the } \\
\text { project. To overcome deadlock the EU Commission offers } \\
\text { European budget financing and redrafts tendering rules to ensure } \\
\text { fair distribution across national space companies. }\end{array}$ \\
\hline D3 & 04.2006 & NeoVal & Lohr & $\begin{array}{l}\text { Siemens-France } \\
\text { (industrial project } \\
\text { leader) }\end{array}$ & $\begin{array}{l}\text { NeoVal (modular automatic transport systems) is one of five initial } \\
\text { programmes launched by AII (now part of Oseo). AII provides } \\
€ 26 \mathrm{~m} \text { subsidies for } 6 \text {-years with } € 60 \mathrm{~m} \text { investment. Approved by } \\
\text { EU Commission. }\end{array}$ \\
\hline D4 & 01.2007 & $\begin{array}{l}\text { Iseult/ } \\
\text { Inumac }\end{array}$ & $\begin{array}{l}\text { Guerbet } \\
\text { laboratories } \\
\text { (joint industrial } \\
\text { project leader) } \\
\text { Alstom MSA } \\
\text { (supraconductor } \\
\text { cables) } \\
\text { CEA } \\
\text { (Commissariat } \\
\text { à l'Energie } \\
\text { Atomique) } \\
\end{array}$ & $\begin{array}{l}\text { Siemens Medical } \\
\text { Solutions (joint } \\
\text { industrial project } \\
\text { leader) } \\
\text { Freiburg } \\
\text { University } \\
\text { Bruker BioSpin } \\
\text { Schering }\end{array}$ & $\begin{array}{l}\text { Iseult/Inumac (imaging of neuro-diseases) is a programme for } \\
\text { industrial innovation selected by the AII's supervisory board. AII } \\
\text { provides } € 55 \mathrm{~m} \text { subsidies for } 5 \text {-8-years with } € 200 \mathrm{~m} \text { investment. }\end{array}$ \\
\hline D5 & 12.2006 & Quaero & $\begin{array}{l}\text { Thompson } \\
\text { (project leader) }\end{array}$ & $\begin{array}{l}\text { Partners: German } \\
\text { subsidiaries of } \\
\text { Thompson; several } \\
\text { German research } \\
\text { enterprises. }\end{array}$ & $\begin{array}{l}\text { Quaero (automatic processing of digital multimedia content) is one } \\
\text { of five initial programmes launched by AII. The R\&D programme } \\
\text { will represent a total cost of } € 199 \mathrm{~m} \text {, including } € 99 \mathrm{~m} \text { of financial } \\
\text { aid from France approved by the EU. First launched as a Franco- } \\
\text { German programme; however due to divergences two distinct } \\
\text { national programmes were launched, Quaero (France) and Theseus } \\
\text { (Germany). Quaero, which still counts German research } \\
\text { organizations, retains a bi-national dimension. }\end{array}$ \\
\hline D6 & 04.2010 & Car alliance & Renault Nissan & Daimler & $\begin{array}{l}\text { The companies exchange stakes to launch a long-term partnership } \\
\text { to build small cars, engines and vans together. }\end{array}$ \\
\hline D7 & 12.2010 & $\begin{array}{l}\text { Strategic } \\
\text { partnership }\end{array}$ & Atos Origin & Siemens & $\begin{array}{l}\text { Siemens takes a } 15 \% \text { stake and a board seat in IT services group } \\
\text { Atos Origin to create Europe's second-largest IT outsourcing } \\
\text { company behind IBM. The deal includes a strategic partnership } \\
\text { with joint investment into software R\&D projects. }\end{array}$ \\
\hline D8 & 07.2011 & $\begin{array}{l}\text { Fostering } \\
\text { collaborative } \\
\text { R\&D } \\
\text { technology } \\
\text { projects } \\
\end{array}$ & OSEO & KFW & $\begin{array}{l}\text { OSEO (French innovation agency providing financial support to } \\
\text { French SMEs) and KFW (German development bank owned by the } \\
\text { government }(80 \%) \text { and the Länder }(20 \%) \text { ) launch EuroQuity. }\end{array}$ \\
\hline
\end{tabular}


